\title{
Immune Skew of Circulating Follicular Helper T Cells Associates With Myasthenia Gravis Severity
}

Shinji Ashida, MD, Hirofumi Ochi, MD, PhD, Mio Hamatani, MD, PhD, Chihiro Fujii, MD, PhD, Kimitoshi Kimura, MD, PhD, Yoichiro Okada, MD, PhD, Yuichiro Hashi, MD, Kazuyuki Kawamura, MD, PhD, Hideki Ueno, MD, PhD, Ryosuke Takahashi, MD, PhD, Toshiki Mizuno, MD, PhD, and Takayuki Kondo, MD, PhD Neurol Neuroimmunol Neuroinflamm 2021;8:e945. doi:10.1212/NXI.0000000000000945

\section{Abstract}

\section{Objective}

To clarify functional alterations of follicular helper $\mathrm{T}$ cells ( $\mathrm{Tfh}$ ) in myasthenia gravis (MG) because Tfh play important roles in helping B cells generate antibody-producing cells.

\section{Methods}

A total of 24 immunotherapy-naive patients with anti-acetylcholine receptor (AchR) antibody-positive MG and 18 age-matched healthy subjects (HS) were enrolled. Samples from 6 patients were available for posttreatment analysis. Subsets of circulating Tfh (cTfh) and B cells were identified by flow cytometry analysis of surface molecules. Cytokine production by isolated cTfh subsets from 5 patients with MG and $5 \mathrm{HS}$ was measured in vitro. Analysis was performed to examine the correlation between the frequency of cTfh subsets and that of plasmablasts and between cTfh subsets and the quantitative MG score.

\section{Results}

cTfh increased with elevated expression of inducible T-cell costimulator (ICOS) in patients with MG. cTfh shifted to Th2 and Th17 over Th1 in MG. ICOS ${ }^{\text {high }}$ cTfh produced significantly higher levels of interleukin (IL)-21, IL-4, and IL-17A than ICOS ${ }^{\text {low }}$ cTfh only in patients with MG. The frequency of cTfh within CD4 T cells was more closely associated with disease severity than the serum anti-AchR antibody titer and frequency of plasmablasts within B cells. Abnormalities of cTfh were improved after immunotherapy in parallel with clinical improvement.

\section{Conclusions}

Alternation of cTfh is a key feature in the development of MG and may become a biomarker for disease severity and therapeutic efficacy.

\section{Classification of Evidence}

This study provides Class II evidence that the level of cTfh is associated with disease severity in patients with MG.

\author{
Correspondence \\ Dr. Kondo \\ takakon78@hotmail.com
}

\section{MORE ONLINE}

$\rightarrow$ Class of Evidence

Criteria for rating

therapeutic and diagnostic

studies

NPub.org/coe 


\section{Glossary}

AchR = acetylcholine receptor $\mathbf{A P C}=$ allophycocyanin $\mathbf{C C R}=\mathrm{C}-\mathrm{C}$ receptor; $\mathbf{c T f h}=$ circulating Tfh; $\mathbf{C X C R 5}=\mathrm{C}-\mathrm{X}-\mathrm{C}$ motif receptor 5; Cy = cyanine; EOMG = early-onset MG; HS = healthy subjects; ICOS = inducible T-cell costimulator; ICOS $^{\text {high }}=$ ICOS high expressing; ICOS $^{\text {low }}=$ ICOS low expressing; IFN = interferon; IL = interleukin; LOMG = late-onset MG; MG = myasthenia gravis; PB = peripheral blood; $\mathbf{P B M C}=$ PB mononuclear cell; $\mathbf{P E}=$ phycoerythrin; $\mathbf{P e r C P}=$ peridinin chlorophyll protein; PMA = phorbol 12-myristate 13-acetate; QGM = quantitative MG; SLE = systemic lupus erythematosus; $\mathbf{T f h}=$ follicular helper $\mathrm{T}$ cells.

Myasthenia gravis (MG) is an antibody-mediated autoimmune disease targeting neuromuscular junctions, characterized by fluctuating muscle weakness with easy fatiguability. ${ }^{1,2}$ About $80 \%$ of patients with MG are positive for anti-acetylcholine receptor (AchR) antibody. ${ }^{2}$ However, the serum concentration of anti-AchR antibody is not always associated with the clinical severity. ${ }^{3-5}$ Hence, it is difficult to clarify the clinical severity based solely on the anti-AchR antibody titer.

Accumulating evidence has shown that follicular helper $\mathrm{T}$ cells ( $\mathrm{Tfh}$ ), chemokine (C-X-C motif) receptor 5 (CXCR5)-expressing CD4 $\mathrm{T}$ cells present in secondary lymph organs, play a vital role in B-cell maturation and antibody production. ${ }^{6-9}$ Tfh preferentially express inducible T-cell costimulator (ICOS), which plays crucial roles in promoting $\mathrm{B}$-cell maturation and antibody production by interacting with the ICOS ligand on B cells. ${ }^{10}$

Although Tfh and antibody-producing cells such as plasma cells ${ }^{11}$ in secondary lymph nodes are a focus of interest in antibody-mediated autoimmune diseases, these cells are difficult to access. Previous studies treated CXCR5+ CD4 $\mathrm{T}$ cells in peripheral blood (PB) as circulating $\mathrm{Tfh}$ (cTfh) and regarded plasmablasts as counterparts of plasma cells in PB. These studies were based on the premise that CXCR5+ $\mathrm{CD} 4 \mathrm{~T}$ cells in PB largely share functional properties with Tfh in secondary lymph nodes and show an increase of cTfh in human antibody-mediated autoimmune diseases, including systemic lupus erythematosus (SLE) ${ }^{12,13}$ rheumatoid arthritis, ${ }^{14}$ Sjögren syndrome, ${ }^{15}$ and neuromyelitis optica. $^{16}$

Evidence shows that Tfh in PB and secondary lymph nodes can be divided into Tfh1, Tfh2, and Tfh17-like total helper $\mathrm{T}$ cells and that Tfh 2 and Tfh 17 more strongly induce antibody production. ${ }^{9}$ Among other cytokines, interleukin (IL)21 is preferentially secreted by Tfh. ${ }^{7,17,18}$ We analyzed cTfh 1 , cTfh2, and cTfh17 shifts in patients with MG and studied cytokine production including IL-21 by cTfh in vitro.

In addition, we analyzed cTfh 1 , cTfh2, and cTfh 17 shifts in patients with MG and studied cytokine production including IL-21 by cTfh in vitro. We analyzed the association of the cTfh phenotype with disease severity in patients with MG and its phenotypic change before and after treatment.

\section{Methods}

\section{Patients}

We included 24 immunotherapy-naive hospitalized patients with MG with anti-AchR antibody attending Kyoto Prefectural University of Medicine, Kyoto University, or Kansai Medical University Medical Center (from March 2017 to November 2018) and 18 age-matched healthy subjects (HS) (table). Six of the 24 immunotherapy-naive patients who could be followed up were analyzed 2-4 weeks after the initiation of all forms of immunotherapy (table).

The clinical data including quantitative MG (QMG) score $^{19}$ were evaluated by neurologists different from those performing flow cytometric analysis, and the serum anti-AchR antibody level (cutoff: $0.2 \mathrm{nmol} / \mathrm{L}$ ) was commercially examined by radioimmunoassay (SRL, Inc., Japan) at the point of blood sample collection.

\section{Standard Protocol Approvals, Registrations, and Patient Consents}

This study was approved by the medical ethics committee of Kyoto Prefectural University of Medicine (RBMR-G-140-1). All subjects provided written informed consent.

\section{Sample Collection and Flow Cytometric Analysis}

PB mononuclear cells (PBMCs) were isolated from fresh blood samples with Lymphocyte Separation Medium 1077 (Wako, Japan) according to the manufacturer's instructions. PBMCs were stained with antibodies from BioLegend (San Diego, CA) unless otherwise stated. CD4 T cells were identified with anti-human CD3 allophycocyanin (APC)-cyanine (Cy) 7 (clone SK7) and anti-human CD4 peridinin chlorophyll protein (PerCP)- Cy5.5 (clone OKT4), anti-human CXCR5 Alexa Fluor 488 (clone J252D4), anti-human ICOS phycoerythrin (PE) (clone C398.4A), anti-human CXCR3 Brilliant Violet 510 (clone 1C6), anti-human C-C receptor (CCR) 6 PE-Cy7 (clone G034E3), and control isotypematched antibodies. To identify B-cell subsets, we used antihuman CD19 PE-Cy7 (clone HIB19), anti-human CD27 APC (clone M-T271) (BD Biosciences, Franklin Lakes, NJ), anti-human CD38 PerCP-Cy5.5 (clone HIT2), and antihuman CD138 pacific blue (clone MI15). The data were acquired using a FACS Canto II flow cytometer (BD Biosciences). Although $\mathrm{T}$ cells were analyzed in all of the enrolled 
Table Patient Background

\begin{tabular}{|c|c|c|c|c|c|c|c|c|c|c|}
\hline \multicolumn{11}{|l|}{ All cases } \\
\hline \multicolumn{5}{|c|}{ Characteristics } & \multicolumn{2}{|l|}{ HS $(n=18)$} & \multicolumn{3}{|c|}{ MG $(n=24)$} & $p$ Value \\
\hline \multicolumn{5}{|c|}{ Age, $y$, mean $\pm S D$} & \multicolumn{2}{|l|}{$45.4 \pm 14.7$} & \multicolumn{3}{|c|}{$51.8 \pm 16.3$} & 0.17 \\
\hline \multicolumn{5}{|c|}{ Sex, female, n (\%) } & \multicolumn{2}{|l|}{$12(67)$} & \multicolumn{3}{|c|}{$12(50)$} & 0.28 \\
\hline \multicolumn{5}{|c|}{ QMG score, mean \pm SD } & \multicolumn{2}{|l|}{-} & \multicolumn{3}{|c|}{$8.2 \pm 4.0$} & - \\
\hline \multicolumn{5}{|c|}{ Thymoma (+), n (\%) } & \multicolumn{2}{|l|}{-} & \multicolumn{3}{|c|}{$7(29)$} & - \\
\hline \multicolumn{5}{|c|}{ EOMG:LOMG } & \multicolumn{2}{|l|}{-} & \multicolumn{3}{|c|}{$11: 13$} & - \\
\hline \multicolumn{5}{|c|}{ Anti-AchR antibody, $\mathrm{nmol} / \mathrm{L}$, mean $\pm \mathrm{SD}$} & \multicolumn{2}{|l|}{-} & \multicolumn{3}{|c|}{$70.3 \pm 16.1$} & - \\
\hline \multicolumn{5}{|c|}{ Disease duration, mo, mean \pm SD } & \multicolumn{2}{|l|}{-} & \multicolumn{3}{|c|}{$7.8 \pm 2.7$} & - \\
\hline \multicolumn{11}{|c|}{ Cases with follow-up samples } \\
\hline \multirow[b]{2}{*}{ Patients } & \multirow[b]{2}{*}{ Age, y } & \multirow[b]{2}{*}{ Sex } & \multirow{2}{*}{$\begin{array}{l}\text { Disease } \\
\text { duration, mo }\end{array}$} & \multirow[b]{2}{*}{ Thymoma } & \multirow{2}{*}{$\begin{array}{l}\text { Time to } \\
\text { follow-up, wk }\end{array}$} & \multicolumn{2}{|c|}{ Anti-AchR Ab, nmol/L } & \multicolumn{2}{|c|}{ QMG score } & \multirow[t]{2}{*}{ Immunotherapy } \\
\hline & & & & & & Pre & Post & Pre & Post & \\
\hline MG 2 & 56 & M & 1.5 & - & 2 & 3.3 & 1.8 & 4 & 0 & CS and tacrolimus \\
\hline MG 7 & 25 & M & 12 & + & 4 & 93 & 45 & 20 & 10 & $\begin{array}{l}\text { CS, tacrolimus, IVIg and } \\
\text { plasma exchange }\end{array}$ \\
\hline MG 10 & 60 & M & 40 & - & 3 & 20 & 20 & 4 & 1 & CS \\
\hline MG 12 & 66 & M & 3 & - & 3 & 17 & 17 & 13 & 4 & CS and IVIg \\
\hline MG 16 & 66 & $\mathrm{~F}$ & 5 & - & 2.5 & 3.3 & 7.6 & 10 & 9 & CS and tacrolimus \\
\hline MG 17 & 52 & $\mathrm{M}$ & 2 & + & 3 & 110 & 61 & 14 & 5 & CS and tacrolimus \\
\hline
\end{tabular}

Abbreviations: AchR = acetylcholine receptor; $\mathrm{EOMG}=$ early-onset MG; LOMG = late-onset MG; $C S$ = corticosteroid; IVIg = IV immunoglobulin; MG = myasthenia gravis; post = posttreatment; pre = pretreatment; $\mathrm{QMG}$ score = quantitative MG score.

subjects, B-cell analysis was performed for 23 patients with MG and 12 HS.

\section{Measurement of Cytokine Production by cTfh}

For analysis of cytokine production, we used PBMCs derived from 5 patients with MG and the same number of HS. PBMCs were stained as indicated above and sorted into CXCR5-positive and -negative CD4 T cells or ICOS high expressing (ICOS ${ }^{\text {high }}$ ) and low expressing (ICOS ${ }^{\text {low }}$ ) CXCR5+ CD4 T cells by Cell Sorter SH800 (Sony, Japan). Sorted CD4 T cells were cultured at a density of $2 \times 10^{5} / \mathrm{mL}$ for 48 hours in AIM-V (Thermo Fisher Scientific, Japan) in 96-well U-bottom plates. Cells were stimulated with phorbol 12-myristate 13-acetate (PMA) and ionomycin cell stimulation (Sigma-Aldrich Co., LLC, St. Louis, MO) during cell culture. The concentration of cytokines was measured in the supernatant with BD CBA flex sets and BD human soluble protein master buffer kits (human IL-21: 560358, human interferon [IFN]- $\gamma$ : 558269, human IL-4 558272, and human IL-17A: 560383), and the data were analyzed using FCAP Array v.3.0 software (BD Biosciences).

\section{Statistical Analysis}

Data are presented as the mean \pm SD. Statistical analysis was conducted with the Mann-Whitney $U$ test for analysis of unpaired data. Spearman rank correlation analysis was used for correlation analysis, and the paired $t$ test was used to assess the difference between before and after treatment. All data sets were analyzed using JMP 13 (SAS Institute Inc., Cary, NC). A $p$ value of $<0.05$ was considered significant.

\section{Data Availability}

The data sets generated and analyzed during the current study are available from the corresponding author on reasonable request.

\section{Results}

\section{Frequency and Phenotypic Analysis of cTfh Within CD4 T Cells}

First, we analyzed cTfh, namely CXCR5 $+\mathrm{CD}^{+} \mathrm{CD}^{+}$ cells, ${ }^{8,9}$ and their expression of ICOS (figure 1, A-C). The frequency of cTfh was determined as a percentage of CD4 $\mathrm{T}$ cells. The frequency of cTfh significantly increased in patients with MG compared with $\mathrm{HS}$ (9.0\% in patients with $\mathrm{MG}$ vs $5.8 \%$ in HS, $p=0.0015$ ) (figure $1, \mathrm{~A}$ and $\mathrm{B}$ ). The frequency of ICOS ${ }^{\text {high }}$ cTfh significantly increased in patients with MG compared with $\mathrm{HS}$ ( $4.0 \%$ in patients with $\mathrm{MG}$ vs $0.9 \%$ in $\mathrm{HS}$, $p<0.0001$ ) (figure 1, A and C). Also, the frequency of 
ICOS ${ }^{\text {high }}$ cells within cTfh was significantly higher in patients with MG than in HS (39.2\% in patients with MG vs $11.6 \%$ in HS, $p<0.001$ ) (figure 1D).

Similarly to total CD4 T cells, cTfh cell subsets included 3 distinct subsets: cTfh1, cTfh2, and cTfh17., ${ }^{6,9,15}$ In this study, we regarded CXCR3+ CCR6- CXCR5+ CD4 T cells as cTfh1, CXCR3- CCR6- CXCR5+ CD4 T cells as cTfh2, and CXCR3- CCR6+ CXCR5+ CD4 T cells as cTfh17 based on previous reports. ${ }^{6,9,15}$ The frequency of cTfh 2 and cTfh 17 within CD4 $\mathrm{T}$ cells was significantly higher in patients with MG than in HS (5.7\% in patients with MG vs $4.2 \%$ in HS, $p=$

Figure 1 cTfh Frequency and ICOS Expression on cTfh and cTfh Subsets

A
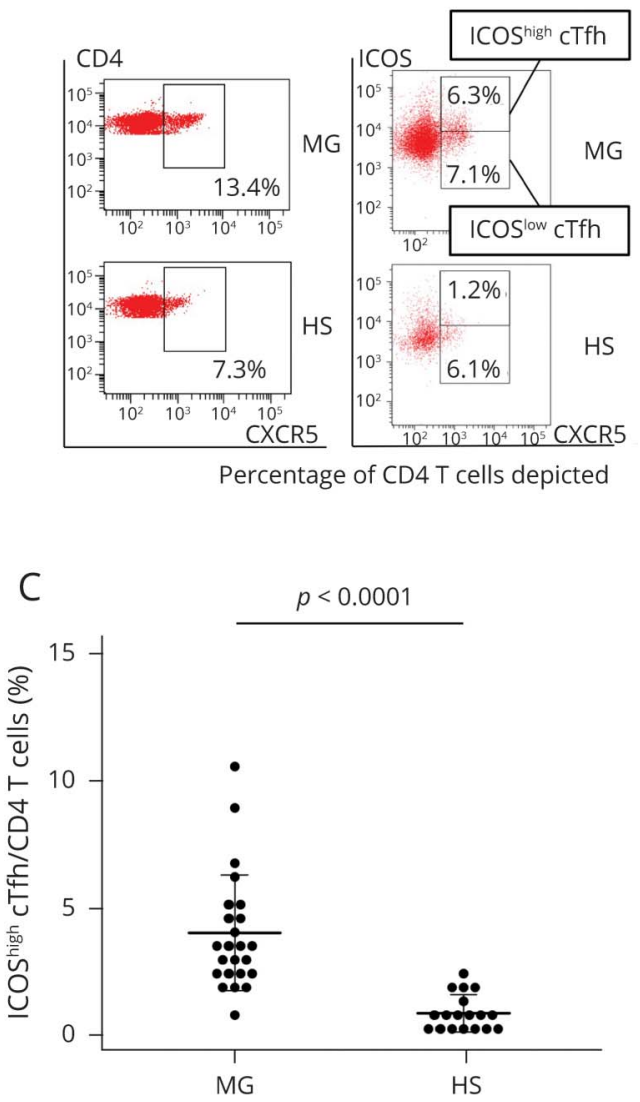

$\mathrm{E}$

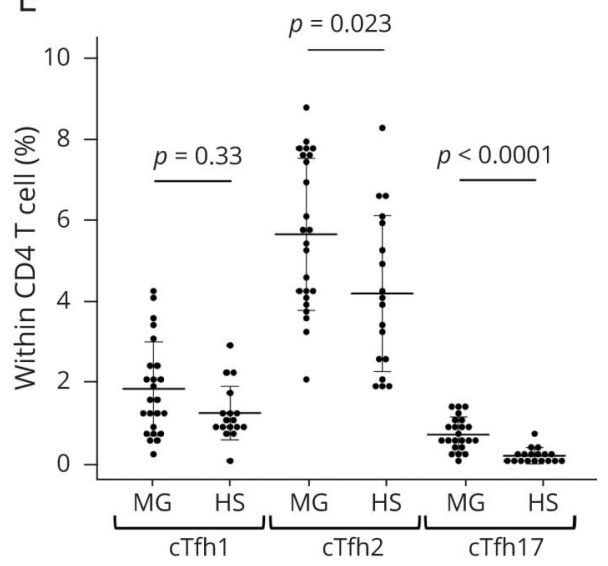

B

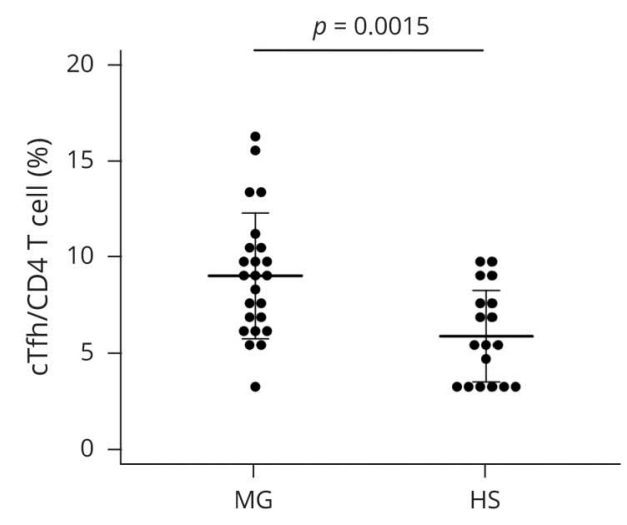

D

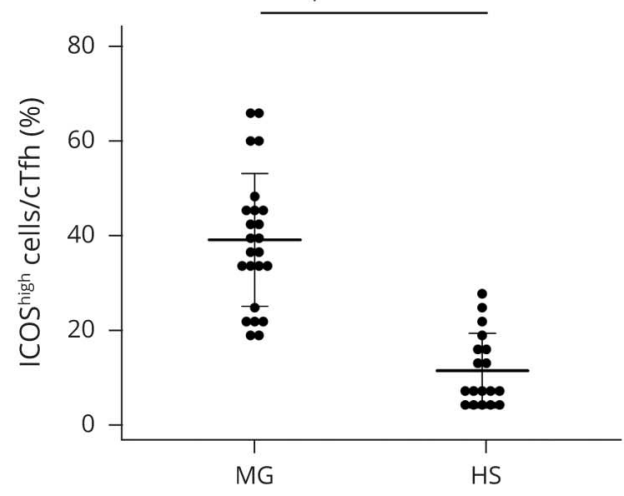

$\mathrm{F}$

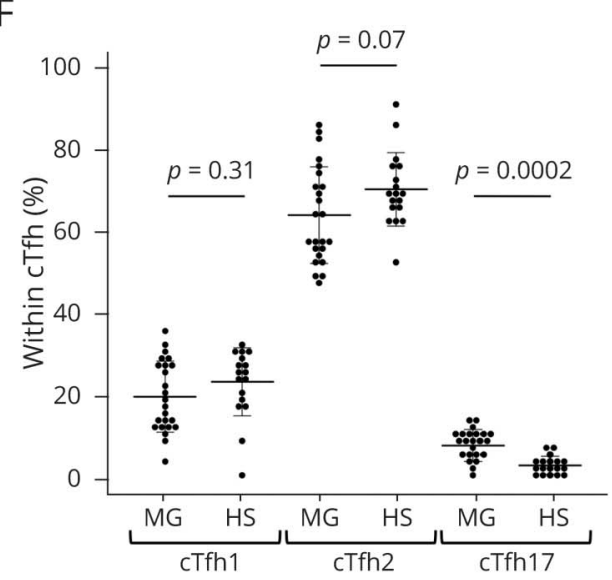

(A) Representative flow cytometry dot plots of CXCR5 expression on CD4 T cells from patients with MG and HS (left) and representative flow cytometry dot plots showing expression of CXCR5 and ICOS (right). (B) Frequency of cTfh within CD4 T cells shown for comparison between patients with MG and HS. Frequency of ICOS ${ }^{\text {high }}$ cTfh within CD4 T cells (C) and within CTfh (D) for comparison between patients with MG and HS. Frequency of cTfh1 (CXCR3+ CCR6cTfh), cTfh2 (CXCR3-CCR6-cTfh), and cTh17 (CXCR3-CCR6+ cTfh) within CD4 T cells (E) and cTfh1, cTfh2, and cTfh17 subsets within cTfh (F) was also analyzed. Data are indicated as the mean \pm SEM. cTfh = circulating follicular helper T cell; $\mathrm{HS}=$ healthy subjects; ICOS = inducible T-cell costimulator; MG = myasthenia gravis; PBMC = peripheral blood mononuclear cell. 
0.023 , and $0.73 \%$ in patients with MG vs $0.21 \%$ in $\mathrm{HS}, p<$ 0.001 , respectively) (figure $1 \mathrm{E}$ ). In addition, the frequency of the Th17 subset within cTfh was significantly higher in patients with MG than in $\mathrm{HS}$ (8.1\% in patients with MG vs $3.2 \%$ in HS, $p=0.0002$ ) (figure $1 F$ ).

\section{Cytokine Production by ICOS ${ }^{\text {high }}$ and ICOS ${ }^{\text {low }}$ cTfh}

We examined cytokine production by cTfh from patients with MG and HS in response to PMA and ionomycin. ICOS ${ }^{\text {h- }}$ ${ }^{\text {igh }}$ cTfh and ICOS ${ }^{\text {low }}$ cTfh were sorted as shown in figure $2 \mathrm{~A}$. There was no significant difference in IFN- $\gamma$ production between patients with MG and $\mathrm{HS}(84.2 \mathrm{pg} / \mathrm{mL}$ in patients with MG vs $154.5 \mathrm{pg} / \mathrm{mL}$ in $\mathrm{HS}, p=0.83$ ) (figure $2 \mathrm{~B}$ ). In contrast, IL-4 and IL-17A production by cTfh was significantly higher in patients with MG than in $\mathrm{HS}(37.0 \mathrm{pg} / \mathrm{mL}$ in patients with MG vs $8.6 \mathrm{pg} / \mathrm{mL}$ in HS, $p=0.012$, and $146.1 \mathrm{pg} / \mathrm{mL}$ in patients with $\mathrm{MG}$ vs $14.7 \mathrm{pg} / \mathrm{mL}$ in $\mathrm{HS}, p=0.037$, respectively) (figure $2 \mathrm{~B}$ ). IL-21 production by cTfh was significantly higher in patients with MG than in HS (129.3 pg/ $\mathrm{mL}$ in patients with $\mathrm{MG}$ vs $20.1 \mathrm{pg} / \mathrm{mL}$ in $\mathrm{HS}, p=0.018$ ) (figure 2B).

We subsequently analyzed cytokine production by ICOS ${ }^{\text {high }}$ and ICOS ${ }^{\text {low }}$ cTfh from patients with MG and HS. ICOS ${ }^{\text {h- }}$ ${ }^{\text {igh }}$ CTfh significantly produced more IL-21 and IL-4 compared

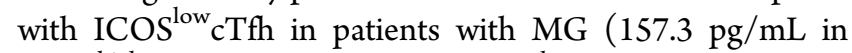
$\mathrm{ICOS}^{\text {high }}$ cTfh vs $19.7 \mathrm{pg} / \mathrm{mL}$ in $\mathrm{ICOS}^{\text {low }}$ cTfh, $p=0.036$ and $57.8 \mathrm{pg} / \mathrm{mL}$ in ICOS ${ }^{\text {high }} \mathrm{cTfh} \mathrm{vs} 6.8 \mathrm{pg} / \mathrm{mL}$ in $\mathrm{ICOS}^{\text {low }} \mathrm{cTfh}$, $p=0.012$, respectively). The production of IL-17A by $\mathrm{ICOS}^{\text {high }} \mathrm{cTfh}$ tended to be higher than that by $\mathrm{ICOS}^{\text {low }} \mathrm{cTfh}$ $\left(152.4 \mathrm{pg} / \mathrm{mL}\right.$ in $\mathrm{ICOS}^{\text {high }}$ cTfh vs $16.4 \mathrm{pg} / \mathrm{mL}$ in ICOS $^{\text {low }}$ cTfh, $p=0.06$ ) (figure $2 \mathrm{C}$ ). ICOS ${ }^{\text {high }}$ cTfh producing higher levels of IL-21 showed higher IL-17A and IL-4 production in patients with MG (figure $2 \mathrm{C}$ ).

\section{Correlation of cTfh With B-Lymphocyte Lineage Cells}

We evaluated subsets of B cells in PB from patients with MG and HS. We defined B-lymphocyte lineage cells as follows: $\mathrm{CD} 19^{+}$cells as B cells, $\mathrm{CD} 19^{+} \mathrm{CD} 27^{+}$cells as memory B cells, and $\mathrm{CD} 19^{+} \mathrm{CD} 27^{+} \mathrm{CD} 38^{\text {high }} \mathrm{CD} 138$ - cells as plasmablasts ${ }^{20}$ (figure e-1A, links.lww.com/NXI/A375). There was no difference in the memory B-cell frequency within B cells between patients with MG and HS (23.7\% in patients with MG vs $23.3 \%$ in HS, $p=0.98$ ) (figure e-1B). Some patients exhibited a higher frequency of plasmablasts than the highest value observed in HS, but there was no significant difference between the 2 groups ( $2.0 \%$ in patients with MG vs $1.2 \%$ in $\mathrm{HS}, p=0.6$ ) (figure e-1C).

Next, we analyzed the correlation between the frequency of plasmablasts and cTfh in patients with MG. The frequency of cTfh within CD4 $\mathrm{T}$ cells and that of plasmablasts within lymphocytes were not significantly correlated $(p=0.5)$ (figure e-1D, links.lww.com/NXI/A375). The frequency of ICOS ${ }^{\text {high }}$ CTfh within CD4 T cells was not associated with that of plasmablasts $(p=0.9)$ (figure e-1E). The frequency of plasmablasts within lymphocytes was also not significantly correlated with the frequency of cTfh 1 or that of cTfh 2 within CD4 T cells ( $p=0.38$ and 0.16 , respectively) (figure e- $1, \mathrm{~F}$ and $G$ ). On the other hand, the frequency of plasmablasts showed a significant correlation with the cTfh 17 frequency within CD4 T cells $\left(R^{2}=0.22, p=0.023\right)$ (figure e-1H).

\section{Association of Disease Severity With Phenotype of cTfh, Anti-AchR Antibody Titer, and Plasmablasts}

We examined the association of disease severity with the cTfh phenotype. The disease severity was significantly correlated with the frequency of cTfh within CD4 T cells $\left(R^{2}=0.35, p=\right.$ 0.005 ) (figure $3 \mathrm{~A}$ ). Furthermore, ICOS ${ }^{\text {high }} \mathrm{cTfh}$ within CD4 $\mathrm{T}$ cells was more significantly correlated with the QMG score than ICOS ${ }^{\text {low }}$ cTfh (ICOS ${ }^{\text {high }}$ cTfh: $R^{2}=0.31, p=0.0038$, and ICOS $^{\text {low }}$ cTfh: $R^{2}=0.17, p=0.039$ ) (figure $3, \mathrm{~A}$ and $\mathrm{B}$ ).

Although the frequency of cTfh1 and cTfh17 within CD4 $T$ cells showed no significant correlation with the QMG score (figure e-2, A and C, links.lww.com/NXI/A376), that of cTfh2 within CD4 $\mathrm{T}$ cells showed a significant correlation with the score $\left(R^{2}=0.22, p=0.02\right)$ (figure $\left.\mathrm{e}-2 \mathrm{~B}\right)$.

There was no correlation between the serum anti-AchR antibody titer or the frequency of plasmablasts and QMG score (figure e-2, D and E, links.lww.com/NXI/A376).

\section{Association of Clinical Characteristics With Phenotype of cTfh}

We compared the phenotype of cTfh between patients with MG with and without thymoma. There was no significant difference in the cTfh frequency within CD4 T cells between patients with MG with and without thymoma (10.1\% and $8.1 \%$, respectively, $p=0.25$ ) (figure e-3A, links.lww.com/ NXI/A377). The frequency of ICOS ${ }^{\text {high }}$ cells within cTfh did not show any significant difference in variability $(38.0 \%$ and $40.4 \%$ in patients with or without thymoma, respectively, $p=0.77$ ) (figure e-3B). There was no clear difference in the cTfh $1, \mathrm{cTfh} 2$, or cTfh 17 frequency within cTfh between patients with MG with or without thymoma (figure e-3C).

Next, we compared the phenotype of cTfh between patients with early-onset MG (EOMG) (aged $<50$ years) ${ }^{1}$ and patients with late-onset MG (LOMG) (aged $\geq 50$ years). ${ }^{1}$ The frequency of $\mathrm{cTfh}$ within $\mathrm{CD} 4 \mathrm{~T}$ cells was significantly higher in patients with EOMG than patients with LOMG (10.8\% in patients with EMOG vs $7.3 \%$ in patients with LOMG, $p=$ 0.019) (figure e-3D, links.lww.com/NXI/A377). This difference should be carefully interpreted because patients with EOMG tended to exhibit a higher QMG score (10.2 in patients with EOMG vs 6.6 in patients with LOMG). On the contrary, there was no significant difference in the ICOS ${ }^{\text {high }}$ cell frequency within cTfh between these 2 groups $(p=0.66)$ (figure e-3E). Furthermore, there was no significant difference 

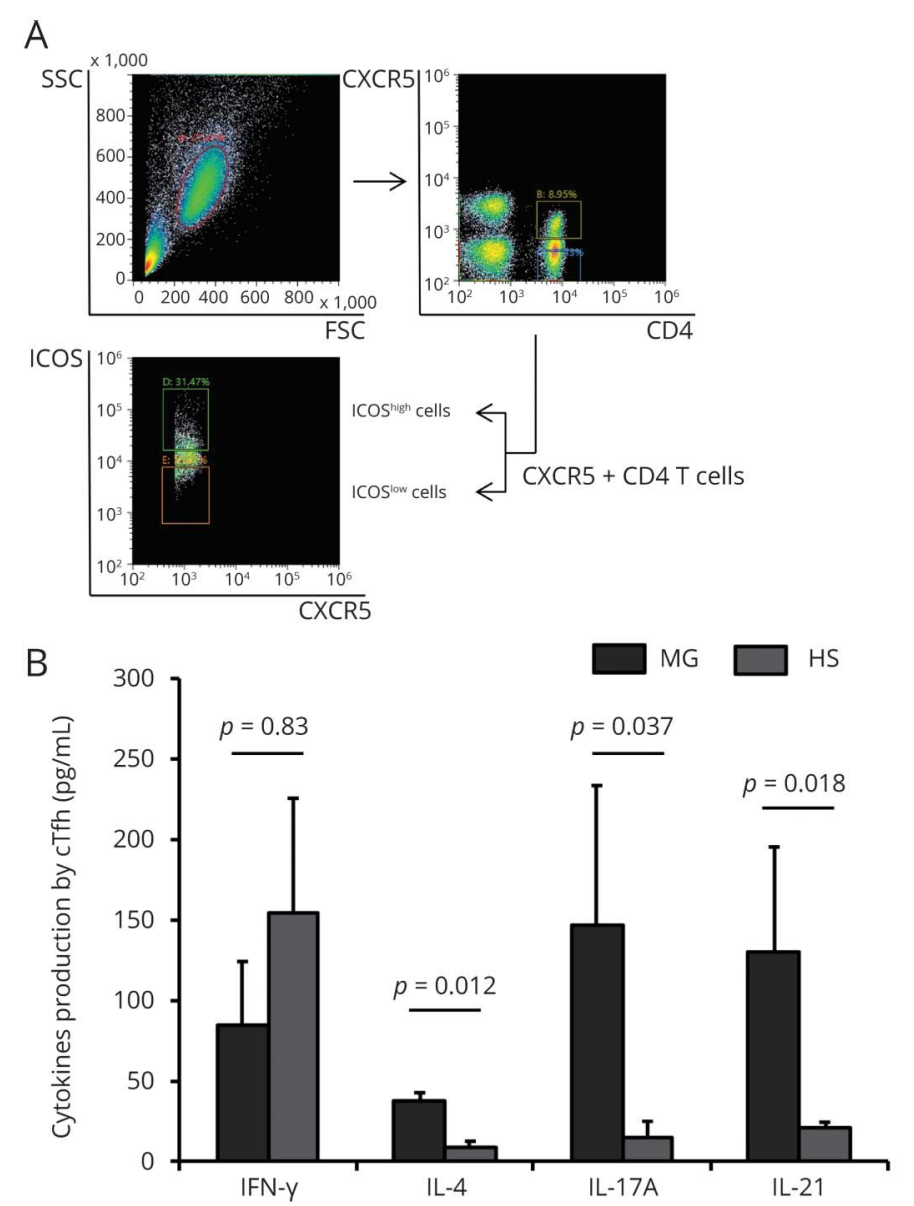

C
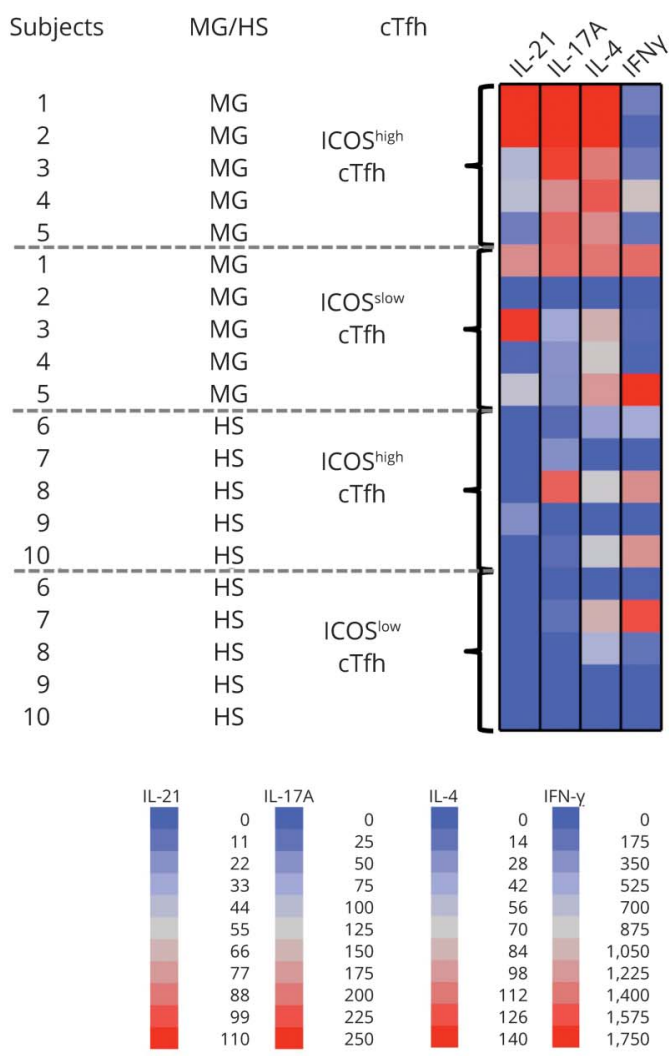

$(\mathrm{pg} / \mathrm{mL})$

cTfh from 5 patients with MG and the same number of HS were cultured under PMA and ionomycin stimulation for 48 hours. CXCR5+CD4 T cells as cTfh, ICOS ${ }^{\text {high }} \mathrm{CTfh}$, and ICOS ${ }^{\text {high }} \mathrm{CTfh}$ were sorted as shown in (A). Levels of IFN-y, IL-4, IL-17A, and IL-21 production by cTfh were measured and compared between patients with MG and HS (B). The heatmap shows cytokine production by ICOS ${ }^{\text {high }}$ and ICOS ${ }^{\text {low }}$ cTfh from patients with MG and HS (C). Each column represents the mean \pm SEM. CCR6 = C-C receptor 6; cTfh = circulating follicular helper T cell; CXCR5 = C-X-C motif receptor 5; HS = healthy subjects; ICOS = inducible T-cell costimulator; IFN-y = interferon-y; IL = interleukin; MG = myasthenia gravis; PMA = phorbol 12-myristate 13-acetate.

in the cTfh1, cTfh2, or cTfh17 frequency within cTfh between patients with EOMG and LOMG (figure e-3F).

\section{cTfh, Plasmablasts, and Anti-AchR Antibody Level After Immunotherapy}

We analyzed the cTfh phenotype before and after starting immunotherapy. All 6 patients showed an improved QMG score after immunotherapy $(p=0.002)$ (figure $3 \mathrm{D})$. The frequency of cTfh and ICOS ${ }^{\text {high }}$ cTfh within CD4 T cells was significantly reduced after immunotherapy $(p=0.04$ and 0.02 , respectively) (figure $3, \mathrm{E}$ and $\mathrm{F}$ ).

The frequency of cTfh 1 and cTfh 2 within CD4 T cells decreased after treatment ( $p=0.1$ and 0.04 , respectively) (figure $\mathrm{e}-4, \mathrm{~A}$ and B, links.lww.com/NXI/A378). The change in the cTfh 17 frequency was the most significant $(p=0.009)$ (figure $\mathrm{e}-4 \mathrm{C}$ ). The frequency of plasmablasts within B cells was reduced in 5 patients after treatment, but without significance ( $p$ $=0.16$ ) (figure e-4D). The serum anti-AchR antibody level tended to decrease (figure e-4E).

\section{Discussion}

In this study, we demonstrated an increase of cTfh in patients with MG, consistent with 2 previous reports. ${ }^{21-23}$ An increased frequency of Tfh was also previously observed in the thymus and thymoma associated with $\mathrm{MG}^{24}$ When we further analyzed cTfh subsets based on the expression of chemokine receptors, cTfh 2 and cTfh 17 dominance over cTfh 1 was observed. Of interest, the frequency of cTfh 2 and cTfh 17 within CD4 $\mathrm{T}$ cells reduced after immunotherapy. The increase of cTfh17 in MG was also reported previously, ${ }^{21}$ and our observation on cTfh2 dominance is not fully consistent with previous reports on MG. ${ }^{21,22}$ Although the patients we analyzed showed acute worsening after onset, the other studies enrolled patients not receiving immunotherapy for more than 2 years. ${ }^{21,22}$ An increased frequency of Tfh 2 was correlated with higher disease activity of SLE. ${ }^{12}$ Taken together, different activities between patients examined may have led to different results. The production of IL-4 and IL$17 \mathrm{~A}$ by cTfh was significantly greater in patients with $\mathrm{MG}$, 


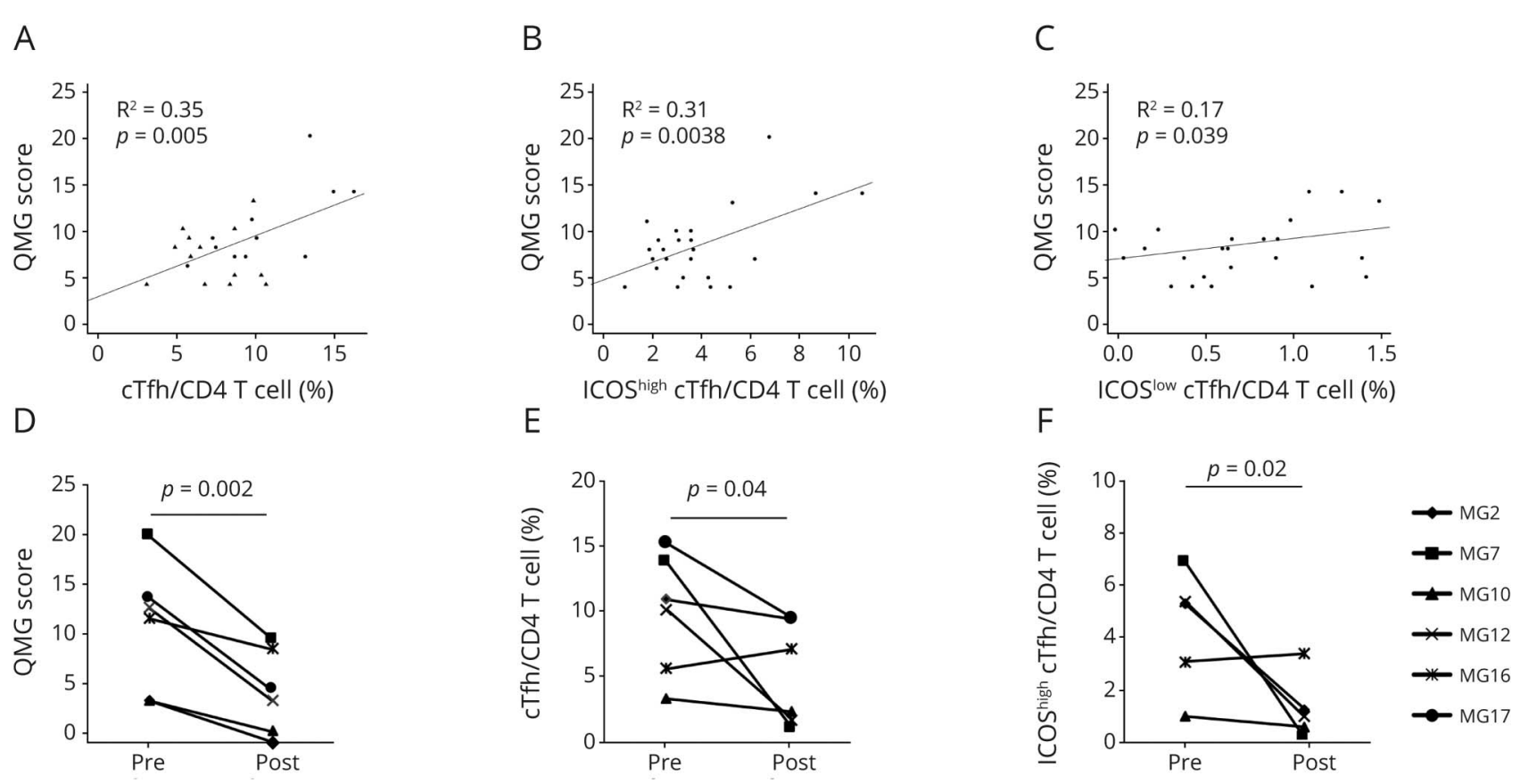

The QMG score was correlated with the frequency of the following subsets within CD4 T cells: (A) cTfh, (B) ICOS ${ }^{\text {high }}$ cTfh, (C) ICOS ${ }^{\text {low }}$ cTfh. In (A), the circle indicates EOMG, and the triangle indicates LOMG. The QMG score and frequency of cTfh subsets within either CD4 T cells or CTfh were analyzed before and after immunotherapy. (D) QMG score. (E) Frequency of $\mathrm{cTfh}$ and (F) ICOS high $\mathrm{CTfh}$ within CD4 T cells. $\mathrm{CTfh}=$ circulating follicular helper T cell; ICOS = inducible Tcell costimulator; $\mathrm{MG}=$ myasthenia gravis; post = after immunotherapy; pre = before immunotherapy; QMG score = quantitative MG score.

which supports the Tfh2 and Tfh17 dominance observed by surface molecule analysis in them.

In this study, we also found that $\operatorname{ICOS}^{\text {high }}$ cTfh increased, and IL-21 production was upregulated in this cTfh subset of patients with MG. The interaction between ICOS on cTfh and its ligand on B cells is essential for B-cell development and antibody production. ${ }^{11}$ ICOS knockout mice were reported to be resistant to clinical experimental autoimmune MG development with lower levels of serum AchR-specific immunoglobulins. ${ }^{25}$ In our analysis, cTfh exhibited significantly higher expression of ICOS in patients with MG compared with HS, a finding in agreement with a recent report. ${ }^{26}$

IL-21 is a key cytokine of $\mathrm{cTfh}^{17,18}$ and promotes B-cell differentiation and antibody production. ${ }^{27-29}$ A study of ICOS-deficient mice reported that effector $\mathrm{T}$ cells showed an impaired ability to produce IL-21 and IL-4, and IgG production was also reduced. ${ }^{25}$ In our study, IL-21 production by cTfh was markedly elevated in patients with MG. IL-21 specifically induces $\operatorname{IgG} 1$ and $\operatorname{IgG} 3$, but not IgG2 nor IgG4. ${ }^{30}$ The preferential production of IL-21 may play an important role in producing anti-AchR antibody that exclusively belongs to IgG1 and IgG3 subclasses. ${ }^{31}$ Of interest, this upregulated IL-21 production was only observed in ICOS ${ }^{\text {high }}$ cTfh in patients with MG. Of note, the production of IL-4 and IL-17A by ICOS ${ }^{\text {high }}$ cTfh from patients with MG increased in parallel with IL-21 (figure 2C). The elevation of IL-21-, IL-4-, and IL-17Aproducing cell frequencies within CD4 T cells in MG was recently reported, supporting our results. ${ }^{26}$ These observations showed that cTfh, especially qualitative and quantitative changes of $\mathrm{ICOS}^{\text {high }} \mathrm{cTfh}$, are essential for the pathogenic cytokine condition in MG. Although ICOS ${ }^{\text {high }}$ Tfh were reported to promote germinal center B cells to produce IgG compared with ICOS ${ }^{\text {low }} \mathrm{Tfh}^{32}$ the functional difference between ICOS ${ }^{\text {high }}$ and $\operatorname{ICOS}^{\text {low }}$ Tfh remains elusive. We reported on enhanced cytokine production by $\mathrm{ICOS}^{\text {high }} \mathrm{cTfh}$ in a human pathologic condition.

IL-21 plays a crucial role in the differentiation of Th17 in the presence of transforming growth factor $\beta^{33,34}$ and that of Tfh themselves in the presence of IL-17. ${ }^{35}$ It was also reported that IL-21 could promote the Th2 response ${ }^{36,37}$ and suppress development of the Th1 response. ${ }^{38}$ Hence, it is likely that the upregulation of IL-21 and ICOS high expression on Tfh is an upstream functional skew to a Th2- and Th17-biased condition and preparation for a condition where pathogenic antibody is produced.

An increase of plasmablasts was reported in several autoimmune disorders including MG. ${ }^{17,39}$ However, the frequency of plasmablasts itself did not reach significance in our study. This suggests that the skew of cTfh is more sensitive to detect the pathogenic condition compared with that of plasmablasts. 
Consistent with previous observations, ${ }^{3-5}$ the anti-AchR antibody titer was not correlated with the disease severity in this study. Anti-AchR antibodies in patients with MG are comprised of antibodies that exhibit different biological activities. ${ }^{3,4}$ The functional activities of antibodies differ among patients, which might explain, at least in part, why titers of antibodies do not correlate with the disease severity.

In contrast and most importantly, quantitative changes in cTfh were correlated with the disease severity in patients with MG, at least before treatment. The presence or absence of thymoma did not influence the frequency of cTfh, ICOS expression, or Th2 or Th17 dominance within cTfh. In addition, elevation of the $\mathrm{cTfh}$ frequency in patients with EOMG compared with patients with LOMG may be attributed to differences in the disease severity between the 2 groups. These facts have raised the possibility that analysis of cTfh can be used as an immunologic marker in MG. This was also supported by the observation that the cTfh frequency decreased in parallel with improvement of the clinical severity.

This study had some limitations. First, this was a small study. We were unable to analyze ICOS ${ }^{\text {high }} \mathrm{cTfh}$ in patients with MG with exacerbation. We could not conclude whether ICOS ${ }^{\text {high }} \mathrm{cTfh}$ is a marker to predict improvement or exacerbation of clinical symptoms because we did not follow up patients with $M G$ at several predetermined points. Hence, a further prospective long-term study is needed to confirm the utility of ICOS ${ }^{\text {high }}$ cTfh as an activity marker of $M G$ in clinical settings.

In conclusion, we revealed that ICOS ${ }^{\text {high }}$ cTfh are elevated and cTfh shift to Th2 and Th17 in MG. Functionally activated Tfh are key features in the immunopathology of MG. Of clinical importance is the fact that the frequency of cTfh was correlated with disease severity in patients with MG.

\section{Acknowledgment}

The authors thank all patients with MG and healthy volunteers who participated in this study. In addition, they thank Dr. Ryusei Nishigori and Dr. Masatsugu Hamaji for their support in collecting patients' samples and clinical data.

\section{Study Funding}

This research was funded by Kansai Medical University and Grant-in-Aid for Research Activity start-up (20K22786).

\section{Disclosure}

S. Ashida, H. Ochi, and M. Hamatani report no disclosures. K. Kimura reports honoraria and grants from the Japan Blood Products Organization, outside the submitted work. C Fujii, Y Okada, Y Hashi C. Fujii, Y. Okada, Y. Hashi, K. Kawamura, H. Ueno, R. Takahashi, T. Mizuno, and T. Kondo report no disclosures. Go to Neurology.org/NN for full disclosures.

\section{Publication History}

Received by Neurology: Neuroimmunology \& Neuroinflammation June 5, 2020. Accepted in final form November 4, 2020.

\section{Appendix Authors}

\begin{tabular}{|c|c|c|}
\hline Name & Location & Contribution \\
\hline $\begin{array}{l}\text { Shinji } \\
\text { Ashida, MD }\end{array}$ & $\begin{array}{l}\text { Graduate School of } \\
\text { Medical Science, Kyoto } \\
\text { Prefectural University of } \\
\text { Medicine, Japan }\end{array}$ & $\begin{array}{l}\text { Designed this study, } \\
\text { analyzed clinical and } \\
\text { biological data, and } \\
\text { contributed to writing the } \\
\text { manuscript }\end{array}$ \\
\hline $\begin{array}{l}\text { Hirofumi } \\
\text { Ochi, MD, } \\
\text { PhD }\end{array}$ & $\begin{array}{l}\text { Ehime University } \\
\text { Graduate School of } \\
\text { Medicine, Toon, Japan }\end{array}$ & $\begin{array}{l}\text { Assisted in data } \\
\text { interpretation and assisted } \\
\text { in writing the manuscript }\end{array}$ \\
\hline $\begin{array}{l}\text { Mio } \\
\text { Hamatani, } \\
\text { MD, PhD }\end{array}$ & $\begin{array}{l}\text { Kyoto University Graduate } \\
\text { School of Medicine, Japan; } \\
\text { Kansai Medical University } \\
\text { Medical Center, Osaka, } \\
\text { Japan }\end{array}$ & $\begin{array}{l}\text { Assisted in experimental } \\
\text { design and data } \\
\text { interpretation and collected } \\
\text { patients' clinical data and } \\
\text { samples }\end{array}$ \\
\hline $\begin{array}{l}\text { Chihiro } \\
\text { Fujii, MD, } \\
\text { PhD }\end{array}$ & $\begin{array}{l}\text { Graduate School of } \\
\text { Medical Science, Kyoto } \\
\text { Prefectural University of } \\
\text { Medicine, Japan }\end{array}$ & $\begin{array}{l}\text { Assisted in experimental } \\
\text { design and data } \\
\text { interpretation }\end{array}$ \\
\hline $\begin{array}{l}\text { Kimitoshi } \\
\text { Kimura, } \\
\text { MD, PhD }\end{array}$ & $\begin{array}{l}\text { Brigham and Women's } \\
\text { Hospital, Harvard Medical } \\
\text { School, Boston, MA }\end{array}$ & $\begin{array}{l}\text { Assisted in experimental } \\
\text { design and data } \\
\text { interpretation and collected } \\
\text { patients' clinical data and } \\
\text { samples }\end{array}$ \\
\hline $\begin{array}{l}\text { Yoichiro } \\
\text { Okada, MD, } \\
\text { PhD }\end{array}$ & $\begin{array}{l}\text { Kansai Medical University } \\
\text { Medical Center, Osaka, } \\
\text { Japan }\end{array}$ & $\begin{array}{l}\text { Assisted in experimental } \\
\text { design and data } \\
\text { interpretation }\end{array}$ \\
\hline $\begin{array}{l}\text { Yuichiro } \\
\text { Hashi, MD }\end{array}$ & $\begin{array}{l}\text { Kansai Medical University } \\
\text { Medical Center, Osaka, } \\
\text { Japan }\end{array}$ & $\begin{array}{l}\text { Assisted in experimental } \\
\text { design and data } \\
\text { interpretation }\end{array}$ \\
\hline $\begin{array}{l}\text { Kazuyuki } \\
\text { Kawamura, } \\
\text { MD, PhD }\end{array}$ & $\begin{array}{l}\text { National Hospital } \\
\text { Organization Minami } \\
\text { Kyoto Hospital, Japan }\end{array}$ & $\begin{array}{l}\text { Assisted in experimental } \\
\text { design and data } \\
\text { interpretation }\end{array}$ \\
\hline $\begin{array}{l}\text { Hideki } \\
\text { Ueno, MD, } \\
\text { PhD }\end{array}$ & $\begin{array}{l}\text { Kyoto University Graduate } \\
\text { School of Medicine, Japan }\end{array}$ & $\begin{array}{l}\text { Assisted and oversaw data } \\
\text { interpretation and } \\
\text { supervised the process of } \\
\text { writing the manuscript }\end{array}$ \\
\hline $\begin{array}{l}\text { Ryosuke } \\
\text { Takahashi, } \\
\text { MD, PhD }\end{array}$ & $\begin{array}{l}\text { Kyoto University Graduate } \\
\text { School of Medicine, Japan }\end{array}$ & $\begin{array}{l}\text { Assisted in writing the } \\
\text { manuscript }\end{array}$ \\
\hline $\begin{array}{l}\text { Toshiki } \\
\text { Mizuno, } \\
\text { MD, PhD }\end{array}$ & $\begin{array}{l}\text { Graduate School of } \\
\text { Medical Science, Kyoto } \\
\text { Prefectural University of } \\
\text { Medicine, Japan }\end{array}$ & $\begin{array}{l}\text { Assisted in data } \\
\text { interpretation and writing } \\
\text { the manuscript }\end{array}$ \\
\hline $\begin{array}{l}\text { Takayuki } \\
\text { Kondo, MD, } \\
\text { PhD }\end{array}$ & $\begin{array}{l}\text { Kansai Medical University } \\
\text { Medical Center, Osaka, } \\
\text { Japan }\end{array}$ & $\begin{array}{l}\text { Assisted and oversaw } \\
\text { experimental design and } \\
\text { data interpretation and } \\
\text { supervised the process of } \\
\text { writing the manuscript }\end{array}$ \\
\hline
\end{tabular}

\section{References}

1. Sieb JP. Myasthenia gravis: an update for the clinician. Clin Exp Immunol 2014;175 408-418.

2. Gilhus N, Verschuuren J. Myasthenia gravis: subgroup classification and therapeutic strategies. Lancet Neurol 2015;14:1023-1036.

3. Aurangzeb S, Tariq M, Irshad M, Badshah M, Khan RS. Relationship between antiacetylcholine receptor antibody titres and severity of myasthenia gravis. J Pak Med Assoc 2009;59:289-292. 
4. Lindstrom J, Seybold M, Lennon V, Whittingham S, Duane D. Antibody to acetylcholine receptor in myasthenia gravis. Prevalence, clinical correlates, and diagnostic value. Neurology 1976;26:1054-1059.

5. Oosterhuis HJ, Limburg PC, Hummel-Tappel E, The TH. Anti-acetylcholine receptor antibodies in myasthenia gravis. Part 2. Clinical and serological follow-up of individual patients. J Neurol Sci 1983;58:371-385.

6. Nakayamada S, Tanaka Y. T follicular helper (Tfh) cells in autoimmune diseases. Jpn J Clin Immunol 2016;39:1-7.

7. Spolski R, Leonard W. IL-21 and T follicular helper cells. Int Immunol 2010;22:7-12.

8. Ueno H, Banchereau J, Vinuesa C. Pathophysiology of $\mathrm{T}$ follicular helper cells in humans and mice. Nat Immunol 2015;16:142-152.

9. Nurieva R, Chung Y, Hwang D, et al. Generation of $\mathrm{T}$ follicular helper cells is mediated by interleukin- 21 but independent of $\mathrm{T}$ helper 1,2 , or 17 cell lineages. Immunity 2008;29:138-149.

10. Nutt SL, Hodgkin PD, Tarlinton DM, Corcoran LM. The generation of antibodysecreting plasma cells. Nat Rev Immunol 2015;15:160-171.

11. Wikenheiser D, Stumhofer J. ICOS co-stimulation: friend or foe? Front Immunol 2016;7:304.

12. Le Coz C, Joublin A, Pasquali JLL, Korganow ASS, Dumortier H, Monneaux F. Circulating TFH subset distribution is strongly affected in lupus patients with an active disease. PLoS One 2013;8:e75319.

13. Simpson N, Gatenby PA, Wilson A, et al. Expansion of circulating T cells resembling follicular helper $\mathrm{T}$ cells is a fixed phenotype that identifies a subset of severe systemic lupus erythematosus. Arthritis Rheum 2010;62:234-244.

14. Ma J, Zhu C, Ma B, et al. Increased frequency of circulating follicular helper $\mathrm{T}$ cells in patients with rheumatoid arthritis. Clin Dev Immunol 2012;2012:827480.

15. Li XY, Wu ZB, Ding J, et al. Role of the frequency of blood CD4(+) CXCR5(+) CCR6(+) T cells in autoimmunity in patients with Sjögren's syndrome. Biochem Biophys Res Commun 2012;422:238-244.

16. Fan X, Jiang $\mathrm{Y}$, Han J, et al. Circulating memory $\mathrm{T}$ follicular helper cells in patients with neuromyelitis optica/neuromyelitis optica spectrum disorders. Mediat Inflamm 2016;2016:1-13.

17. Spolski R, Leonard W. Interleukin-21: a double-edged sword with therapeutic potential. Nat Rev Drug Discov 2014;13:379-395.

18. Tian Y, Zajac A. IL-21 and T cell differentiation: consider the context. Trends Immunol 2016;37:557-568

19. Barnett C, Katzberg H, Nabavi M, Bril V. The quantitative myasthenia gravis score: comparison with clinical, electrophysiological, and laboratory markers. J Clin Neuromuscul Dis 2012;13:201-205.

20. Maecker H, McCoy J, Nussenblatt R. Standardizing immunophenotyping for the Human Immunology Project. Nat Rev Immunol 2012;12:191-200.

21. Yang Y, Zhang M, Ye Y, Ma S, Fan L, Li Z. High frequencies of circulating Tfh-Th17 cells in myasthenia gravis patients. Neurol Sci 2017;38:1599-1608.

22. Zhang CJ, Gong Y, Zhu W, et al. Augmentation of circulating follicular helper T cells and their impact on autoreactive B cells in myasthenia gravis. J Immunol 2016;197:2610-2617.
23. Luo C, Li Y, Liu W, et al. Expansion of circulating counterparts of follicular helper T cells in patients with myasthenia gravis. J Neuroimmunol 2013;256 $55-61$

24. Song Y, Zhou L, Miao F, et al. Increased frequency of thymic T follicular helper cells in myasthenia gravis patients with thymoma. J Thorac Dis 2016;8 314-322.

25. Scott B, Yang H, Tüzün E, Dong C, Flavell R, Christadoss P. ICOS is essential for the development of experimental autoimmune myasthenia gravis. J Neuroimmunol 2004 153:16-25.

26. Çebi M, Durmus H, Aysal F, et al. CD4 + T cells of myasthenia gravis patients are characterized by increased IL-21, IL-4, and IL-17A productions and higher presence of PD-1 and ICOS. Front Immunol 2020;11:809.

27. Moens L, Tangye S. Cytokine-mediated regulation of plasma cell generation: IL-21 takes center stage. Front Immunol 2014;5:65.

28. Ettinger R, Sims G, Fairhurst AM, et al. IL-21 induces differentiation of human naive and memory B cells into antibody-secreting plasma cells. J Immunol 2005; 175 : 7867-7879.

29. Ozaki K, Spolski R, Feng CG, et al. A critical role for IL-21 in regulating immunoglobulin production. Science 2002;298:1630-1634.

30. Pène J, Gauchat JF, Lécart S, et al. Cutting edge: IL-21 is a switch factor for the production of IgG1 and IgG3 by human B cells. J Immunol 2004;172:5154-5157.

31. Rødgaard A, Nielsen FC, Djurup R, Somnier F, Gammeltoft S. Acetylcholine recepto antibody in myasthenia gravis: predominance of IgG subclasses 1 and 3. Clin Exp Immunol 1987;67:82-88.

32. Bentebibel SEE, Schmitt N, Banchereau J, Ueno H. Human tonsil B-cell lymphoma 6 (BCL6)-expressing CD4+ T-cell subset specialized for B-cell help outside germinal centers. Proc Natl Acad Sci USA 2011;108:E488-E497.

33. Zhou L, Ivanov II, Spolski R, et al. IL-6 programs T(H)-17 cell differentiation by promoting sequential engagement of the IL-21 and IL-23 pathways. Nat Immunol 2007;8:967-974.

34. Korn T, Bettelli E, Gao W, et al. IL-21 initiates an alternative pathway to induce proinflammatory TH17 cells. Nature 2007;448:484.

35. Ding Y, Li J, Wu Q, et al. IL-17RA is essential for optimal localization of follicular. Th cells in the germinal center light zone to promote autoantibody-producing B cells. J Immunol 2013;191:1614-1624.

36. Pesce J, Kaviratne M, Ramalingam TR, et al. The IL-21 receptor augments Th2 effector function and alternative macrophage activation. J Clin Invest 2006;116: 2044-2055

37. Fröhlich A, Marsland BJ, Sonderegger I, et al. IL-21 receptor signaling is integral to the development of Th2 effector responses in vivo. Blood 2007;109:2023-2031.

38. Suto A, Wurster AL, Reiner SL, Grusby MJ. IL-21 inhibits IFN-gamma production in developing Th1 cells through the repression of Eomesodermin expression. J Immunol 2006; 177:3721-3727.

39. Almaani S, Rovin BH. B-cell therapy in lupus nephritis: an overview. Nephrol Dial Transplant 2019;34:22-29. 


\title{
Neurology $^{\odot}$ \\ Neuroimmunology \& Neuroinflammation
}

\author{
Immune Skew of Circulating Follicular Helper T Cells Associates With Myasthenia \\ Gravis Severity \\ Shinji Ashida, Hirofumi Ochi, Mio Hamatani, et al. \\ Neurol Neuroimmunol Neuroinflamm 2021;8; \\ DOI 10.1212/NXI.0000000000000945
}

This information is current as of January 12, 2021

Updated Information \&

Services

References

Subspecialty Collections

Permissions \& Licensing

Reprints including high resolution figures, can be found at:

http://nn.neurology.org/content/8/2/e945.full.html

This article cites 39 articles, 8 of which you can access for free at: http://nn.neurology.org/content/8/2/e945.full.html\#\#ref-list-1

This article, along with others on similar topics, appears in the following collection(s):

Autoimmune diseases

http://nn.neurology.org//cgi/collection/autoimmune_diseases

Myasthenia

http://nn.neurology.org//cgi/collection/myasthenia

Information about reproducing this article in parts (figures,tables) or in its entirety can be found online at:

http://nn.neurology.org/misc/about.xhtml\#permissions

Information about ordering reprints can be found online:

http://nn.neurology.org/misc/addir.xhtml\#reprintsus

Neurol Neuroimmunol Neuroinflamm is an official journal of the American Academy of Neurology.

Published since April 2014, it is an open-access, online-only, continuous publication journal. Copyright

Copyright (C) 2021 The Author(s). Published by Wolters Kluwer Health, Inc. on behalf of the American

Academy of Neurology.. All rights reserved. Online ISSN: 2332-7812.

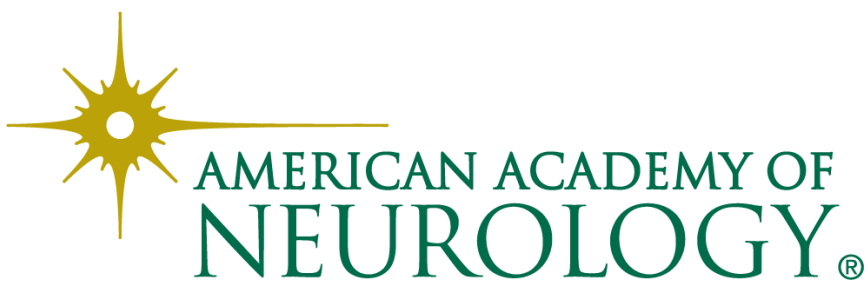

